\title{
Comparison of The Use of Number and Type of Spark Plugs on One Cylinder Gasoline Machine Performance
}

\author{
Ahmad Fariza \\ Mechanical Engineering Department \\ State Polytechnic of Malang \\ JIn. Soekarno Hatta 9 \\ Malang, Jawa-Timur, INDONESIA \\ ahmadfariza34@gmail.com \\ Yuniarto Agus Winoko \\ Mechanical Engineering Department \\ State Polytechnic of Malang \\ JIn. Soekarno Hatta 9 \\ Malang, Jawa-Timur, INDONESIA \\ dhimazyuni@gmail.com \\ Umi Anis Ro'isatin \\ Mechanical Engineering Department \\ State Polytechnic of Malang \\ Jin. Soekarno Hatta 9 \\ Malang, Jawa-Timur, INDONESIA \\ umianisr@gmail.com
}

The basic concept of a combustion motor is to convert chemical energy into heat energy and then convert it to mechanical energy. Heat energy is produced from the combustion process between a mixture of fuel and air with a pressure difference triggered by spark (flame). The objective is to determine the difference in power, torque, and average effective pressure by adding the number of spark plugs and using the standard type of spark plug and iridium on a single-cylinder engine. The engine performance testing method uses P-max to get power, while the analysis uses experimental design, the data processing method uses DOEfactorial and the Minitab application 18. Power test for a standard spark plug resulted in $7.93 \mathrm{HP}, 0.89 \mathrm{kgm}$ torque and $1207.66 \mathrm{kPa}$ average effective pressure. For iridium spark plug the test produced $9.02 \mathrm{HP}$, it is $0.91 \mathrm{~kg} . \mathrm{m}$ for torque and average effective pressure is $1226.32 \mathrm{Kpa}$. For two standard spark plugs, the power was $9.38 \mathrm{HP}$, torque was $0.93 \mathrm{~kg} . \mathrm{m}$, and the average effective pressure was $1269.96 \mathrm{kPa}$. Whereas the two iridium spark plugs produced $9.59 \mathrm{HP}, 0.91 \mathrm{~kg} . \mathrm{m}$ torque, and $1277.78 \mathrm{kPa}$ average effective pressure.

Keywords: Number of Spark Plugs, Type of Spark Plug, Engine Performance

\section{INTRODUCTION}

The combustion process in a combustion engine occurs due to chemical reaction, i.e. reaction between a mixture of fuel and air with a pressure difference triggered by a lighter (fire). The octane number of fuel, the air that enters the combustion chamber and a good ignition system, so that the spark plug can sprinkle large sparks, greatly affect the combustion process. The spark plug ignition system serves to trigger sparks in the combustion chamber. Sparks will ignite a mixture of fuel and air. One way to get perfect combustion is to increase the intensity of the ignition of spark plugs on the spark plug [1].

The ignition timing factor and the spark plug flame distribution influence the combustion process in the combustion chamber. To reduce the amount of fuel that does not burn completely, it requires a second stage combustion process (continued combustion) so that all fuel can be burned completely. The use of two spark plug variations is expected to provide a more even distribution of combustion to increase combustion efficiency, power, engine torque, and average effective pressure.

In the study of Cahyadi [2] the effect of the use of double spark plugs and double CDI on the power of Yamaha Jupiter z $110 \mathrm{cc}$ motorcycle stated that the use of double spark plugs with double CDI increased the maximum shaft power by 5,649 HP. The power generated by using double spark plugs and double CDI has increased by $0.823 \mathrm{HP}$ or about $17.05 \%$ of the standard state (single spark plug and single CDI).

Aminudin [3] investigated the effect of dual spark ignition on engine performance and exhaust emissions 
on a 4-stroke single-cylinder gasoline engine concluded that the use of two spark plugs in one cylinder can increase power by $8.6 \mathrm{HP}$ at $6000 \mathrm{rpm}$ engine speed, where an increase of $14.67 \%$ compared to standard machine conditions. At this study, the use of iridium spark plugs can increase power by $12.02 \%$, increase torque by $8.42 \%$, and an average effective pressure increase of $12.02 \%$ on a new standard engine.

\section{MATERIALS AND METHODS}

\subsection{Combustion Process}

The combustion process is a chemical reaction that takes place quickly between fuel, oxygen, and a lighter that produces heat energy and combustion gases [4]. The process of combustion on a gasoline motor starts from the moment the lighter sparks. Ignition angle of $15^{\circ}$ before TDC (Supra X125). Proper ignition affects combustion. The result of combustion reaction depends on the composition and quality of the combustion process. Combustion occurs when the moving piston has not reached TDC, so the ignition must occur before TDC. Ignition angle is $15^{\circ}$ before TDC, because the appropriate angle adjustment produces optimum power.

When ignition time is advanced too far, a backfire (backfire) or detonation occurs that results in power drops, overheating or the engine suddenly dies. When the ignition is too backward, the combustion process takes place when piston moves from top dead centre (TDC) to bottom dead centre (BDC), so that the gas pressure becomes optimum when the piston leaves the TDC. This condition results in a decrease in engine power, wasteful of fuel, and overheating [4].

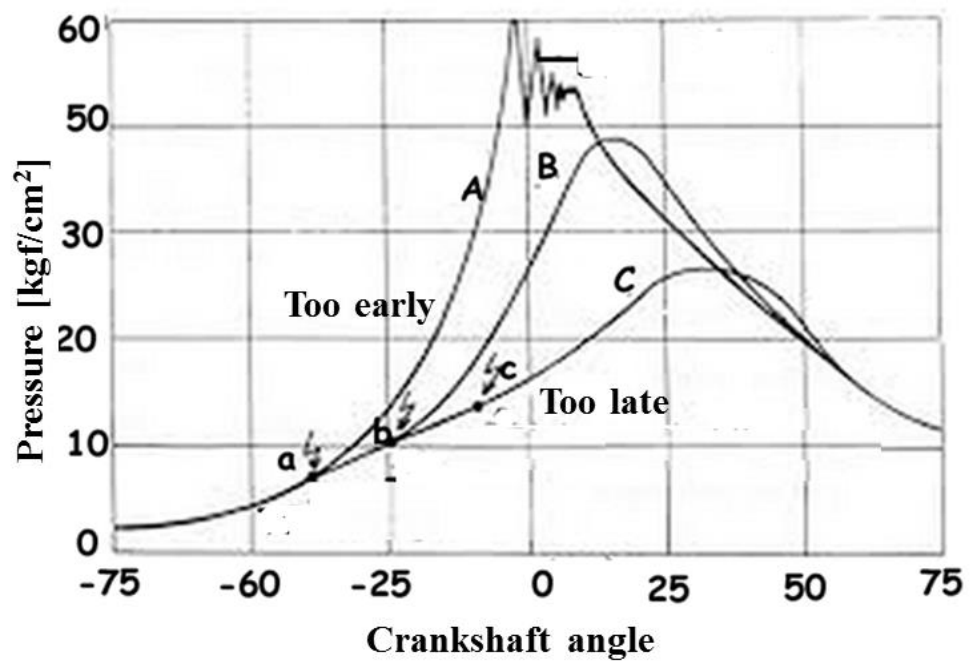

Figure 1. Influence of ignition time to power on combustion chamber [4]

\subsection{Ignition system}

Spark plugs sparks the mixture of fuel and compressed air. Thus, mixture will ignite so that the and create gas expansion (explosive) combustion [5]. Gasoline engine ignition systems can efficiently work when compression pressure is high. It occurs only at correct ignition timeand correct air-to-fuel ratio. Strong sparks in the combustion chamber are useful when the air and fuel are compressed for effective combustion. The ability of spark plugs to produce sparks is influenced by several factors including the shape of the spark plug electrode, spark plug gap and compression pressure [1].

\subsection{Engine performance}

Engine performance is defined as the ability of engine to produce energy in one cycle that is used to move an object or tool. Testing the performance of the engine aims to obtain optimum thermal efficiency. Engine performance consists of power, torque, fuel consumption, average effective pressure, and thermal efficiency [4].

\subsection{Engine power}


Engine power is defined as energy produced by the engine for every one-time unit. Power is important to achieve engine's top speed. In motor vehicles, there are 2 types of power, namely the indicator power, i.e. the power generated from the combustion of gas in the cylinder, and mechanical power, i.e. the power generated by the engine to drive the shaft (eq. 1) [4].

$$
\mathrm{N}_{\mathrm{e}}=\frac{\mathrm{T} \times \mathrm{n}}{716.2}
$$

where:

$$
\begin{aligned}
& \mathrm{N}_{\mathrm{e}} \text { : Effective power (Ps). } \\
& \mathrm{T} \quad \text { : Torque }(\mathrm{Nm}) . \\
& \mathrm{n} \quad \text { : Engine speed (rpm). }
\end{aligned}
$$

\subsection{Torque}

Torque is the force used to rotate an object on its axis. Torque are the piston force when moving down multiplied by the distance from the middle of the crankpin to the center of the crankshaft. The torque performance graph shows how the piston presses the crankshaft with how much force when the combustion motor is rotating which is passed on to the wheel. Torque is needed to move the piston from a stationary position to move [6] and can be calculated using eq. 2 [7]

$$
\mathrm{T}=\frac{716,2 \times \mathrm{N}_{\mathrm{e}}}{\mathrm{n}}
$$

where:

$\mathrm{T}:$ Torque $(\mathrm{Nm})$.

$\mathrm{N}_{\mathrm{e}}$ : Effective shaft power (Hp).

$\mathrm{n}$ : Engine speed (rpm).

\subsection{The average effective pressure (BMEP)}

The average effective pressure or break man effective pressure (BMEP) is a theoretical constant pressure, on the piston during the working step will produce the same network per cycle as the actual one. Bmep is also a constant pressure which results in a net output of work while causing the piston to move as far as the same stroke volume as the actual cycle [8]. The average effective pressure according to Heywood can be formulated in eq. $3[6]$.

$$
\mathrm{BMEP}=\frac{\mathrm{P} \times \mathrm{n}_{\mathrm{R}} \times 10^{3}}{\mathrm{~V}_{\mathrm{d}} \times \mathrm{N}}
$$

where:

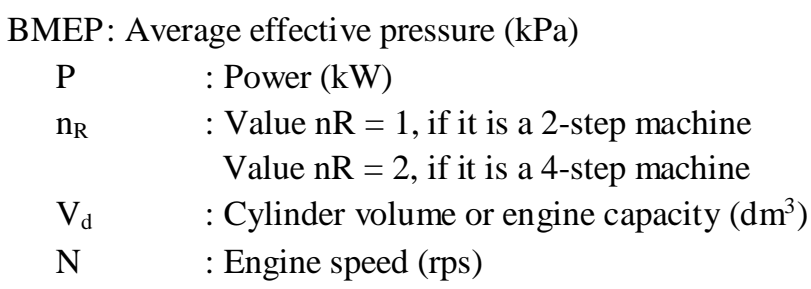

\section{RESEARCH METHODOLOGY}

Data retrieval is done by determining the control variable, the independent variable and the dependent variable. In this study Variable control is the engine speed at 40, 45, 50, 55, 60, 65, 70, 75, 80, 85, 90, 95, 100, $105 \mathrm{~km} / \mathrm{h}$. The independent variable in this study is the number and type of spark plugs in one cylinder. The dependent variable in this study is engine performance, namely power, torque, and BMEP (Break Mean Effective Pressure). 


\subsection{Tool design}

Figure 2. Schematic drilling of a cylinder head

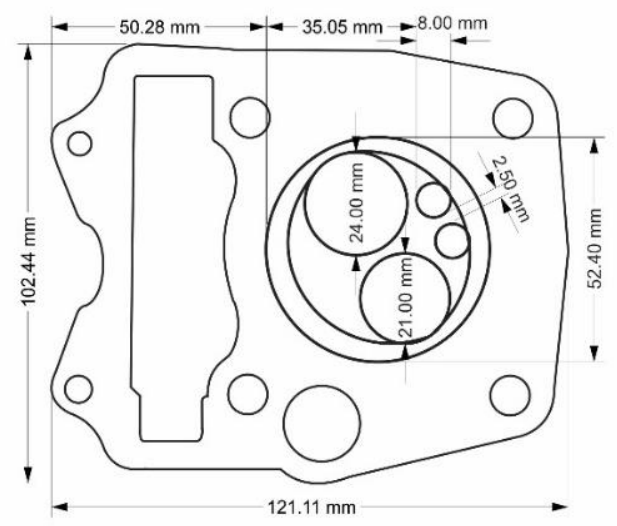

The addition of spark plug holes in one cylinder by punching holes in the right cylinder head next to the standard spark plug hole. The distance between spark plug one and spark plug two is $2.50 \mathrm{~mm}$. the diameter of the spark plug holes one and spark plug two is $8 \mathrm{~mm}$ (Figure 2). Modification of the ignition system with the aim to get the ignition time of the second spark plug does not coincide with the first spark plug, so it is necessary to add a pulse to the ignition system.

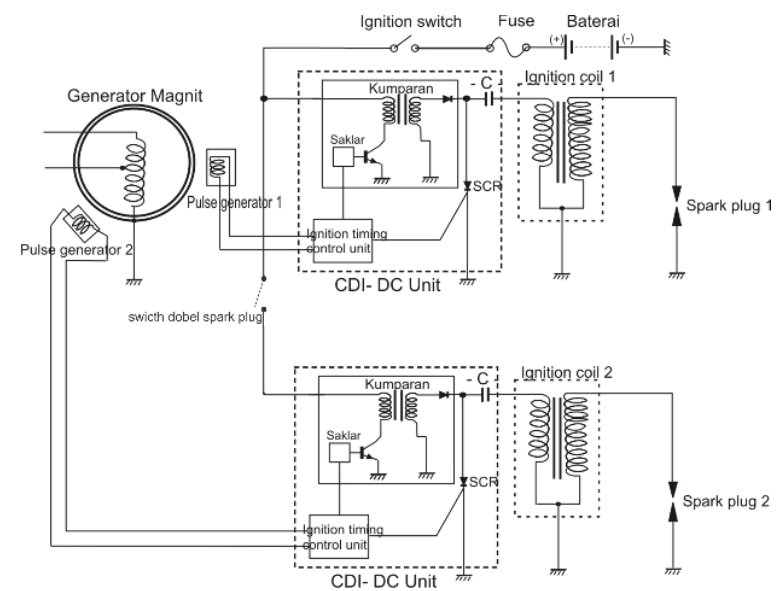

Figure 3. Electrical schematic on two spark plugs

The electrical scheme works when the ignition switch and the double spark plug switch are ON and the current flows from the positive battery to the current amplifier coil in CDI-1 and CDI-2 which increases the battery voltage from 12 -volt DC to 220 Volts AC. Then the current is directed through the diode and then flowed into the condenser for temporary storage (Figure 3). As a result of the engine rotation, pulse generators 1 and 2 produce a current which then activates the SCR, thus triggering a capacitor to flow current to the primary coil of the ignition coil.

In the event of a disconnection of the current flowing in the primary coil of the ignition coil, the induced voltage arises in the two coils, namely the primary coil and the secondary coil. As a result of induction in the coil, causing a spark jumps on the spark plugs so that the first combustion occurs in the combustion chamber. When the ignition is in the OFF position, the current from the positive battery does not flow in the current amplifier coil, so that the CDI is not active and there is no ignition in the combustion chamber.

\subsection{Data Retrieval}

The research data was obtained using a dyno test device connected to the computer (Figure 4). The engine 
performance testing method uses P-max Full open throttle. The first step is to raise the motorcycle on the dyno test and then tie the front wheel to the motorcycle holder. Tie the back of the motorcycle with webbing sling on the dyno test with the same tightness. Turn on the dyno test computer and enter the vehicle specifications on the computer. Turn on the motorcycle until it reaches work temperature, then do the data retrieval.

Figure 4. Testing scheme

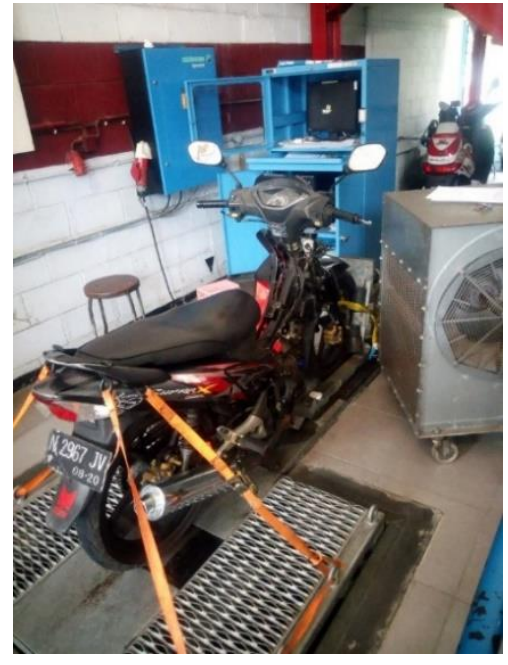

Data was collected by pulling the gas handle until the engine speed reaches $105 \mathrm{~km} / \mathrm{h}$, accompanied by adding gear acceleration gradually until the maximum gear after that the gas handle is maximally opened until the engine speed reaches its maximum limit. The results of the test will be displayed on the computer from the dyno test.

\section{RESULT AND DISCUSSION}

\subsection{POWER}

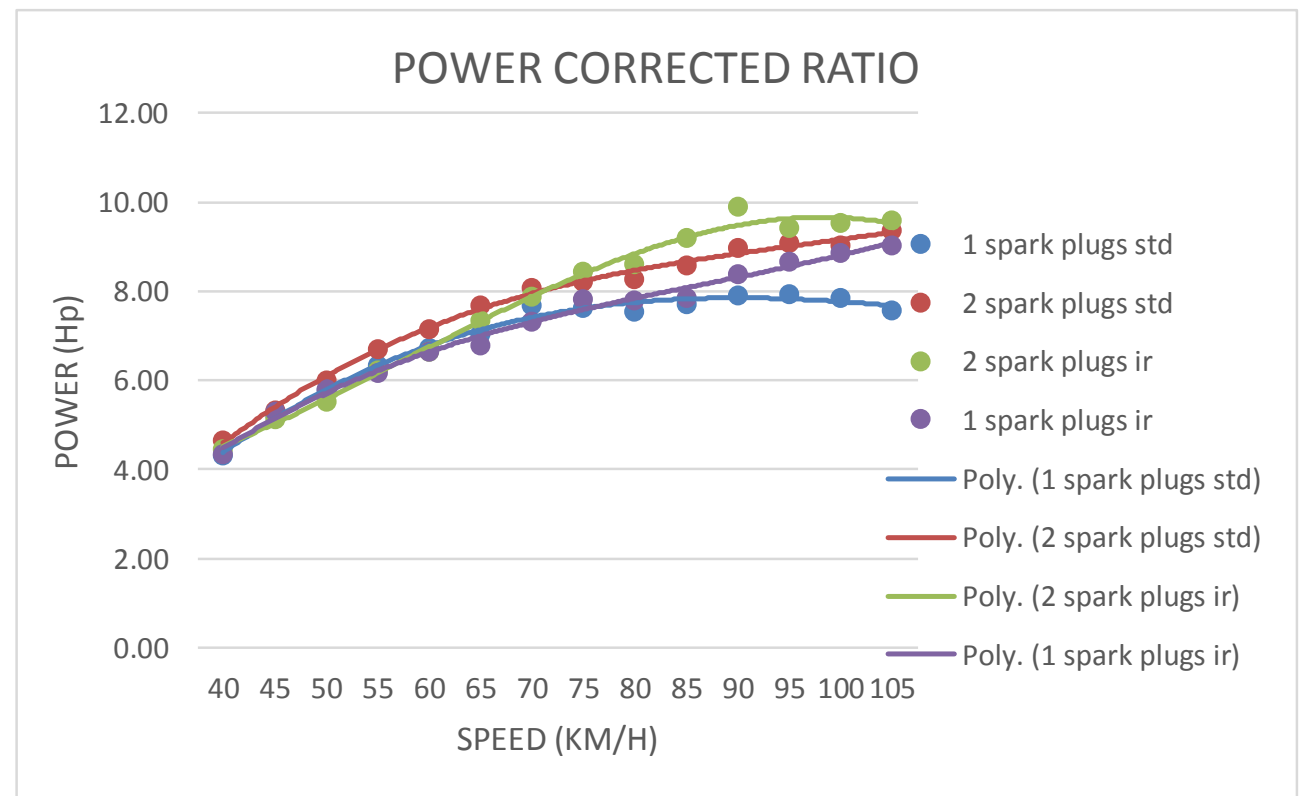

Figure 5. Comparison graph of the effect of the number and type of spark plugs on power

In Figure 5 it can be concluded that the maximum power produced by an engine with 1 (one) standard spark plug is $7.93 \mathrm{HP}$. In the use of two spark plugs the maximum power standard obtained is $9.38 \mathrm{HP}$. On the use of one iridium spark plug, the maximum power obtained is $9.02 \mathrm{HP}$. In the use of two iridium spark plugs the maximum power obtained is $9.59 \mathrm{HP}$. 
The power in using one spark plug and two spark plugs is different. Where the use of two spark plugs the power produced is greater than one spark plug. The increase in power in the engine with two spark plugs due to the combustion of fuel is more perfect when compared to standard engines. That is because at high rotations the ignition time of the spark plug becomes faster so that the combustion of fuel and air in the combustion chamber becomes perfect or there is no fuel wasted and energy (power) increases with an increase in en gine speed followed.

The use of spark plug types can also affect the combustion process, wherein the use of iridium spark plug types the power produced is greater than the standard spark plug types. This is caused by the characteristics of the spark plugs where the standard spark plugs at the end of the electrodes are flat while the iridium spark plugs are more pointed. So that the spark plug iridium spread of the fire becomes more directed and causes a more optimal combustion process.

\subsection{TORQUE}

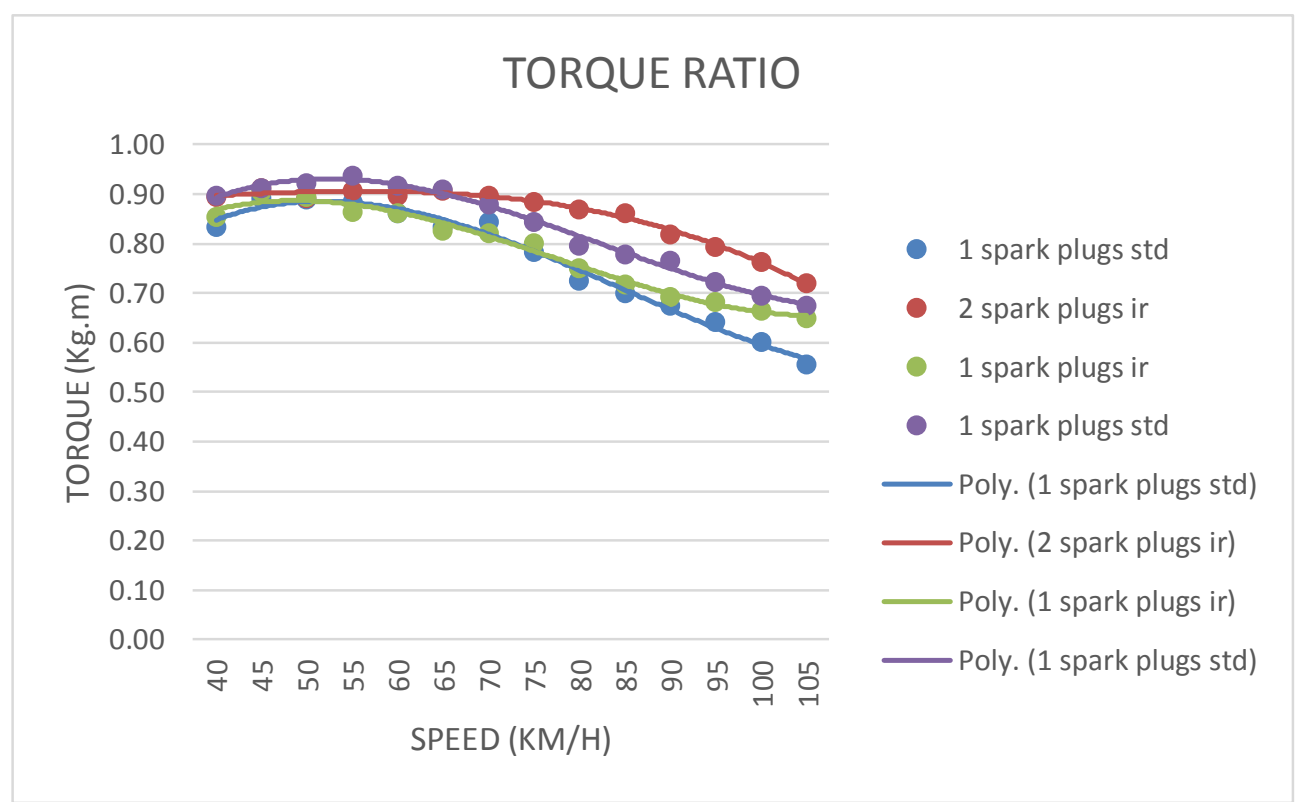

Figure 6. Comparison on the effect of the number and type of spark plugs on torque

From Figure 6 it can be concluded that the maximum torque produced by an engine with 1 (one) standard spark plug is $0.89 \mathrm{kgm}$. In the use of two standard spark plugs the maximum torque obtained is $0.93 \mathrm{kgm}$. In the use of one iridium spark plug, the maximum torque obtained is $0.91 \mathrm{kgm}$. In the use of two iridium spark plugs the maximum torque obtained is $0.91 \mathrm{kgm}$.

The effect of the pressure and temperature of the combustion chamber on an engine with two spark plugs increases, this condition which can affect the energy produced by the engine. As a result of the greater energy produced, the pounding received by the piston is also greater, so that the torque produced by the vehicle increases. Also, the radius of the crankshaft also affects the results of torque. From the graphic image above shows that the use of two spark plugs can increase torque on a motorcycle.

\subsection{BMEP}

The maximum B mep produced by an engine with 1 (one) standard spark plug was $1207.66 \mathrm{kPa}$ at a speed of $45 \mathrm{~km} / \mathrm{h}$ (Figure 7). When two standard spark plugs was used, the maximum Bmep was $1269.96 \mathrm{kPa}$ at a speed of $55 \mathrm{~km} / \mathrm{h}$. When one iridium spark plug was used, the maximum BMEP obtained was $1226.32 \mathrm{kPa}$ at a speed of $45 \mathrm{~km} / \mathrm{h}$. When two Bmep iridium spark plugs was used, a maximum BMEP of $1277.78 \mathrm{kPA}$ was obtained at a speed of $45 \mathrm{~km} / \mathrm{h}$. 


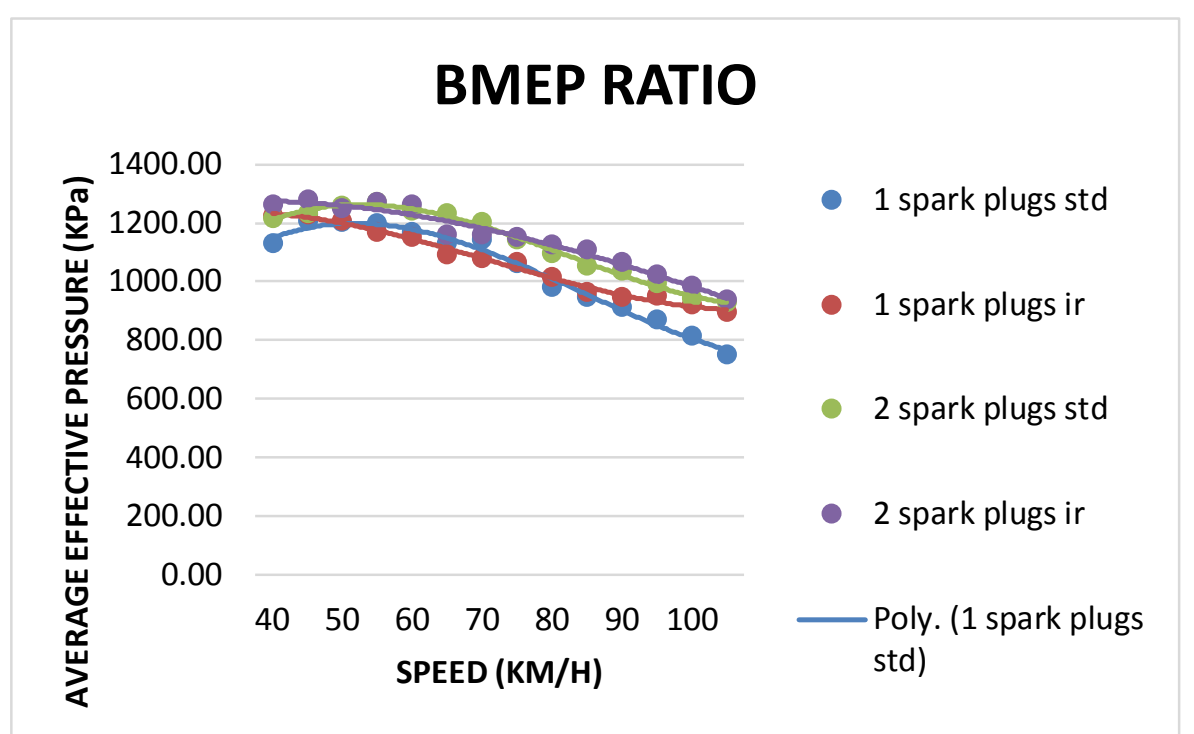

Figure 7. Comparison on the effect of the number and type of spark plugs on BMEP

The difference in average effective pressure results between one and two spark plugs is caused by combustion in an engine with two spark plugs having better fuel combustion compared to one spark plug so that the engine working temperature is faster and the combustion chamber pressure will increase.

\section{CONCLUSION}

Based on the test data that has been done, it can be concluded several important things about the effect of variations in the number and type of spark plugs on the power, torque, and average effective pressure (BMEP) of a $124.82 \mathrm{cc} 1$-cylinder motor. There is a difference in the use of one spark plug and two spark plugs on the average power, torque and effective pressure. There are differences in the use of standard spark plugs and iridium spark plugs on average power, torque, and effective pressure. There is also difference in the number of spark plugs and the type of spark plug on the power, torque, and average effective pressure.

\section{ACKNOWLEDGMENTS}

Praise be to God, the author extends the presence of Allah for his blessings, mercy, and hid any so that the preparation of the final research report can be completed: the final project entitled "Comparison of the number and type of spark plugs on one cylinder gasoline machine performance can be completed with the support of several parties particularly the faculty members and staffs of Mechanical Engineering Department of State Polytechnic of Malang.

\section{REFERENCES}

[1] KURNIAWAN, H., "Pengaruh penggunaan busi standar, busi racing, dan busi iridium terhadap kinerja mesin sepeda motor 4 langkah $110 \mathrm{cc}$ pada berbagai tekanan kompresi, Undergraduate final project, Fakultas Teknik Universitas Negeri Semarang, 2016.

[2] CAHYADI, K.M., "Pengaruh penggunaan busi ganda terhadap daya sepeda motor Yamaha Jupiter Z tahun 2009” Jurusan Pendidikan Teknik dan Kejuruan, Universitas Sebelas Maret, 2009.

[3] AMINUDIN, A., "Pengaruh dual spark plug ignition terhadap performa mesin dan emisi gas buang pada 4-stroke gasoline engine single cylinder, Balikpapan, Politeknik Negeri Balikpapan, 2017.

[4] WINOKO, Y.A., "Pengujian Daya dan Emisi Gas Buang", Malang, Polinema Pers, 2017

[5] JAMA, J., Teknik Sepeda Motor Jilid 2 untuk SMK. Jakarta, Direktorat Pembinaan Sekolah Menengah Kejuruan, 2008.

[6] HEYWOD. B., Internal Combustion Engine Fundamental, Mc Graw-Hill Book Company. New York, 1998.

[7] ARISMUNANDAR, W., Penggerak Mula Motor Bakar Torak, Penerbit ITB, Bandung, 1994.

[8] MATHUR AND SHARMA, Internal Combustion Engine, Dhampat Rai \& Sons, New Dehli India, 1980. 